\title{
Simboliniai žaidimai užsienio politikoje: Rusijos ir Didžiosios Britanijos santykiai 2006-2008 m.
}

\begin{abstract}
Analizuojant 2006-2008 m. Didžiosios Britanijos ir Rusijos dvišaliu santykių problemas per simbolinių žaidimų užsienio politikoje koncepciją parodoma, kaip Rusija sugebëjo sukurti ir išlaikyti asimetrinį dvišalių santykių su Didžiaja Britanija pobūdį, leidusį turèti santykių ir problemų apibrěžimo iniciatyvą bei formuoti savas žaidimo taisykles. Straipsnyje ne tik atskleidžiama, kaip iš pažiūros lyg ir dẻl nereikšmingos istorijos dvi šalys gali ilgai nesutarti, bet ir parodoma, kaip „pralaimimi“ simboliniai užsienio politikos žaidimai visu pirma dẻl to, kad nesusigaudoma, koks žaidimas yra žaidžiamas.
\end{abstract}

\section{Ivadas}

2007 metu pabaigoje Rusijos valdžios atstovai vis intensyviau ir garsiau reiškè nepasitenkinimą Britų Tarybos veikla jų šalyje, reikalaudami nuo 2008 $\mathrm{m}$. sausio $1 \mathrm{~d}$. uždaryti visus ne Maskvoje isteigtus šios institucijos padalinius ${ }^{1}$. Kuo prasikalto ši, Didžiosios Britanijos finansiškai remiama agentūra, kurios pagrindinis deklaruojamas siekis Rusijoje - mokyti jaunimą anglu kalbos bei siūlyti jiems studijų stipendijas Britanijoje²?

Kaltinimai teisinio statuso neapibrèžtumu ar mokesčių vengimu daugumai stebėtojų ne Rusijoje ir patiems britams tereiškè, jog už visų priekaištu ir reikalavimų slypi „politiniai“ motyvai ${ }^{3}$.Šioje situacijoje nesutarimu motyvo įvardijimas „politiniu“ reiškẻ nuostatą, jog Rusija dèl visai kitu priežasčiu puolanti britų instituciją, kad vadovaujasi kitais nežinomais/slaptais/neišsakomais motyvais. Bene svarbiausias pagrindas taip manyti buvo Rusijos

\footnotetext{
* Dr. Dovilè Jakniūnaité - Vilniaus universiteto Tarptautinių santykių ir politikos mokslų instituto lektorè. Adresas: Vokiečių g. 10, 01130 Vilnius; tel. 85 2514130, el. paštas - dovile.jakniunaite@tspmi.vu.lt.

1 Žr., pavyzdžiui, Министерство иностранных дел Российской Федерации, Комментарий официального представителя МИД России М.Л.Камынина в связи с решением Британского Совета приостановить деятельность региональньх отделений в России 2007, 12 декабря, http://www.mid.ru/ns-reuro.nsf/ 348bd0da1d5a7185432569e700419c7a/432569d80022027ec32573d400384fc8?OpenDocument, žiūrèta 2008-08-04.

2 Žr. British Council, About us, http://www.britishcouncil.org/new/about-us/, žiūrèta 2008-07-12. Taip pat Britų tarybos Rusijoje internetini puslapi http://www.britishcouncil.org/ru/russia.htm, žiūrèta 2008-07-12.

3 Wingfield-Haye, R., Russia's new front in UK spat, BBC News, 2007, December 13, http://news.bbc. co.uk/2/hi/europe/7141708.stm, žiūrèta 2008-09-12.
} 
atstovu prisimintas 1995 m. įstatymas „Dèl užsienio kultūros ir informacijos centrų steigimo tvarkos ir veiklos sąlygų Rusijos Federacijos teritorijoje" , kuriuo remiantis ir buvo vykdomas Britų Tarybos puolimas ${ }^{4}$. Tad kilo visai logiški klausimai - kodèl atakos suintensyvejjo būtent 2007 m. pabaigoje, o ne tuomet, kai įsigaliojo įstatymas, kuo „iš tikrujų“ neįtiko institucija ir ko Rusija siekè?

Svarbu ir tai, kad Britu Tarybos problemos Rusijoje nebebuvo vien tik vienos institucijos darbo keblumas. Nuo 2006-ujų metų vis prastëjančių Rusijos ir Didžiosios Britanijos santykiu kontekste šis klausimas tapo puikiu pavyzdžiu, iliustruojančiu augančią dvišalę įtampą, aiškiau prasidejjusią dar $2006 \mathrm{~m}$. pradžioje „,šnipų skandalu“ ir taip ir nenumalšusią po Londono „nunuodijimo bylos“ 2006 metų rudeni. Iškylant tai vienoms, tai kitoms problemoms ${ }^{5}$ įtampa tarp šių dviejų valstybių nesiliovè iki 2008 m. vidurio, kai tiek vienos, tiek kitos dėmesi patraukė reikšmingesni tarptautinès politikos įvykiai (visų pirma 2008 m. rugpjūčio pradžioje prasidejęs konfliktas Gruzijoje). Beveik trejus metus nesiliovę intensyvūs dvišaliai nesutarimai neišsirutuliojo i̇ audringą konfliktą ar tarptautinės politikos problemą. Tačiau praktikoje jų užteko sukurti abipusi nepasitikèjimą, nuolatos balansuojantį ties atviro priešiškumo pasireiškimo riba.

Analizuojant dvišalę valstybių užsienio politiką šis atvejis leidžia formuluoti mažiausiai du išsamesnio svarstymo reikalaujančius klausimus. Pirma, kas vyksta ir ką reiškia, kai techniniai, daugiau mažiau rutininio pobūdžio, nesutarimai tampa santykių indikatoriumi ir problema tarp valstybių? Antra, kodèl valstybės įsivelia į tokio pobūdžio konfliktus? Kitaip tariant, straipsnyje laikomasi prielaidos, kad išanalizavus ir supratus Rusijos ir Didžiosios Britanijos ginčo dinamiką atskirais „mikro“" klausimais ir valstybių elgesio strategijas jose, įmanoma tiksliau suprasti valstybių užsienio politikos elgseną bei geriau nusakyti bendrus dabartinius dvišalius valstybių santykius.

Straipsnyje pasirinkta perspektyva į dvišalių santykių įvykius žiūri kaip į simbolinį žaidimą. İvairiausi žaidimai, kuriu pagrindinis tikslas - netiesiogiai nusiųsti kokį nors pranešimą kitai pusei, užsienio politikoje toli gražu nẻra didelẻ naujiena. Tam naudojamos įvairiausios diplomatinės priemonés. Pripažįstama, kad diplomatija gali būti ir dažnai yra naudojama simboliškai, netiesiogiai siekiant strateginio pranašumo užsienio politikoje. Kita vertus, bet kuris kasdienės dvišalès užsienio politikos įvykis netampa viešosios diplomatijos problema. Kas pasirenkama kaip viešumos reikalaujantis dalykas ir kaip tai įvyksta užsienio politikoje yra ne mažiau svarbu nei bandymas suvokti, kokių tikslų siekiant tai daroma.

Taigi šio straipsnio tikslas yra analizuojant pastarujų trejų metų Didžiosios Britanijos ir Rusijos dvišalių santykių problemas (tarpusavio „žaidimus“) atskleisti simbolinių žaidimų užsienio politikoje vaidmenị ir parodyti, kaip Rusija sugebejjo sukurti ir išlaikyti asimetrinį dvišalių santykių su Didžiąja Britanija pobūdi, leidusį turèti santykių ir problemų ap(s)ibrèžimo iniciatyvą bei formuoti

\footnotetext{
4 Комментарий официального представителя МИД России М.Л.Камынина.

5 Pradedant įvairiausias ,šnipų“ skandalais, ,,apsižodžiavimais“ ir baigiant nesutarimais komercijoje.
} 
savas ,„žaidimo“ taisykles ${ }^{6}$. Straipsnyje ne tik atskleidžiama, kaip iš pažiūros gana nereikšminga istorija gali tapti savaitès, net mėnesio dvišalių santykių ịvykiu, bet ir parodoma, kaip „pralaimimi“ simboliniai užsienio politikos žaidimai visu pirma dẻl to, kad nesusigaudoma, koks žaidimas yra žaidžiamas.

Pirmoje straipsnio dalyje yra išplètojama užsienio politikos sąveikos (simbolinių žaidimu) ir jų analizès koncepcija. Toliau atliekama Didžiosios Britanijos ir Rusijos dvišalių santykių 2006-2008 m. analizè, besiaiškinant, kaip įmanoma iššifruoti įtampą tarp šių valstybiu, naudojantis tripakopiu modeliu, analizuojančiu vertybinị konteksta, faktus ir dialogą. Paskutinëje, išvadu, straipsnio dalyje svarstoma simbolinių žaidimų reikšmè valstybės užsienio politikoje ir jų analizės perspektyvos.

\section{Kasdienybè ir žaidimai užsienio politikoje}

Didžioji dalis valstybės užsienio politikos susideda iš rutininių veiksmų ir aiškiu procedūrų. Rašomi raštai, rengiami dvišaliai ir daugiašaliai vizitai, tarptautiniai renginiai, ruošiamos pozicijos tarptautinėse organizacijose, derybų grupėse, derinamos nuomonės, įvyksta susitikimai, kuriuose didžioji dalis kalbų ir raštu netampa viešai svarbūs. Žinoma, netapimas viešais toli gražu nereiškia, kad šie veiksmai nereikšmingi. Jie gali lemti pokyčius, svarbius įvykius, tačiau dažnai palaipsnius ir daugumai mūsų nematomus. Tai kas valstybių užsienio politikoje yra matoma - valstybės lyderių vieši ir šventiniai susitikimai, iškilmingi dokumentų pasirašymai, garsūs grasinimai ar kritika kitoms valstybèms - susiformuoja dèl šių dažniausiai nematomu, kasdieniu užsienio politikos procesų.

Viešoji, dažnai proginè, užsienio politikos pusė pritraukia gerokai daugiau ir komentatoriu, ir tyrëju dèmesio. Tai yra puiki ir nesunkiai randama medžiaga interpretuoti valstybių elgesi, jų motyvus, identifikuoti jų interesus ir ilgalaikius siekius. Bent jau gana dažnai yra daroma prielaida, kad viešoji politika atskleidžia "tikruosius" valstybių interesus ir strateginius planus. Arba gali būti pasirenkama kita analizès strategija - turint teorinių teiginiu sistemą apie tai, kodèl valstybė elgiasi vienaip ar kitaip, interpretuojami konkretūs kasdieniai ar proginiai įvykiai. Abiem atvejais dažniausiai daroma prielaida, kad įmanoma aiškiai žinoti ir identifikuoti valstybės interesus, kad jie yra daugmaž stabilūs, apibrèžti ir natūraliai kyla iš tam tikrų valstybès charakteristikų.

Tokiam mąstymui yra būdinga nuostata, kad valstybių viešoji užsienio politika yra instrumentiné, siekianti valstybès (nacionalinių) interesu ir kartu pati tuos interesus išreiškianti arba signalizuojanti apie jų pasikeitimą. Taigi į valstybių veikimą tokia perspektyva žiūri kaip į strategini, dažniausiai nuoseklų, sistemingą elgesị. Šiame straipsnyje ją galima pavadinti „makro“ žiūra,

\footnotetext{
${ }^{6}$ Analizès laikotarpis - 2006-2008 m. 2006 m. pradžioje įvykęs pirmasis ryškesnis incidentas, kaip paaiškẻjo vėliau, buvo pirmasis prastėjančių dvišalių santykių indikatorius, pakankamai aiškiai nurodęs ir šios analizès chronologines ribas.
} 
nes visų pirma apibrėžia valstybės bendrus veikimo principus, o paskui juos naudoja konkrečių įvykių ar reiškiniu paaiškinimui ${ }^{7}$.

Pats savaime toks žiūros būdas nèra ydingas. Duotybėmis laikomos nuostatos apie valstybių veikimą bet kokiu atveju buvo suformuluotos remiantis nusistovejusių praktikų apibendrinimu. Tačiau čia jis problemiškas dèl dviejų dalykų. Pirma, suformuluoti bendri valstybių elgesio dėsningumai yra paverčiami beveik gamtos dèsniais. Antra, šie dėsningumai formuluojami taip bendrai, kad šios bendrosios valstybių veikimo teorijos nesuteikia įrankiu analizuoti konkrečių valstybių konkrečias sąveikas (kitaip tariant, nenurodo, kaip atlikti žemesnio analitinio lygmens empirinius tyrimus).

I viešus tarpvalstybinius nesutarimus (arba apskritai valstybių užsienio politikos įvykius) galima žiūrèti ir kitaip. Juos galima laikyti socialinėmis praktikomis, kurių metu valstybės ne tiek deklaruoja (implikuoja) savo tikslus, kiek formuluoja savo pačios ir santykiu partnerio apibūdinimus, konstruodamos juos viešose „mikro“ dvikovose. Šių sąveikų taisyklès labai dažnai konstruojamos tuo pat metu viešuose susidūrimuose.

Socialinės praktikos yra itin svarbios bet kokioje socialinëje sąveikoje, nes jos yra tie reguliarumai ir veiksmai, kurie susieja socialinę struktūrą su atskiru subjektų veikimu. Praktikos taip pat yra indikatoriai, leidžiantys identifikuoti struktūrinius apribojimus ir veikejjo subjektyvumą ${ }^{8}$. Būtent socialinėse praktikose susiformuoja sąvokos ir jų reikšmès (t. y. įvyksta įvardijimas, angl. naming): „mes remiamės ju nurodomu įprastu sugebejjimu reprodukuoti reikšmę tam tikroje situacijoje ir tam tikrame veiksme, kad dar kartą patvirtintumėme arba modifikuotume ju reikšmę $e^{\prime \prime}$.

Tokiu būdu nedaroma išankstiniu prielaidų apie tai, ko valstybė siekia elgdamasi vienu ar kitu būdu, o siekiama, kad pats veiksmas atskleistų veikimo ir sąveikų reikšmes. Tokia perspektyva klausia, kaip pačios valstybès sąveikaudamos viena su kita formuluoja savo interesus, tikslus ir siekius, o kartu kuria, perkuria ir tarpusavio žaidimo taisykles bei įvardijimus. Būtent per dvišales sąveikas formuojasi abipusės interpretacijos. Todèl analizès dèmesio centre visu pirma turi būti praktikų analizè.

Praktikų analizė taip pat leidžia nusakyti viešų ir neviešų užsienio politikos procesų santyki. Šioje perspektyvoje viešų žaidimų erdvè suformuluoja pagrindą ir kontekstą, kuriame tampa įmanoma didžioji dalis kasdienių, „nematomu“" veiklų. Veikimas neįmanomas be idejju. Jas Laffey ir Weldes vadina „simbolinėmis technologijomis“, pabrèždami, kad jos yra intersubjektyviu

\footnotetext{
${ }^{7}$ Be abejo, tradicinis realizmo terminas irgi tiktų. Šiuo atveju, jo pradinė nuostata traktuoti valstybes kaip žinomus ir prognozuojamus (pagal jų tikslus ir interesus, kuriuos nulemia jų gebejjimai, dažnai suprantami kaip galia), santykinai stabilius tarptautinès sistemos darinius. Didžiausia metodologinė tokio teorinio mąstymo problema - savaime išsipildančios hipotezės (angl. self-fulfilling hypotheses).

8 Plačiau žr. Jakniūnaitè, D., Kur prasideda ir baigiasi Rusija: kaimynystè tarptautineje politikoje, Vilnius, Vilniaus universiteto leidykla, 2008, pirma dalis.

9 McSweeney, B., Security, Identity and Interests: A Sociology of International Relations, Cambridge: Cambridge University Press, 1999, p. 161.
} 
reprezentaciju sistemos, o taip pat ir reprezentacijas kuriančios praktikos ${ }^{10}$. Kitaip tariant, idejjos yra socialios, jos nèra individualaus lygmens fenomenai, jos kolektyvinès, bendros. Idejos atsiranda dèl kolektyvinių socialiniu veiksmu. Tai reprezentacijų sistemos, kurios susiformuoja specifinëje erdvinëje laikinèje bei kultūrinejje aplinkoje ir kurios leidžia cirkuliuoti daugiau mažiau artikuliuotoms reikšmių sistemoms. Tad idëjos irgi yra socialinèse praktikose susiformuojančios socialinès praktikos.

Kokių galimybių šis požiūris apie idejjų (reikšmių) vaidmenį socialiniu praktiku procesuose suteikia analizuojant dvišales užsienio politikos sąveikas? Jis leidžia suvokti reikšmių svarbą ir konkurenciją socialinėse sąveikose. Galima pasinaudoti Barnett pasiūlyta užsienio politikos samprata - užsienio politika tai normatyvinès struktūros ir strateginio veikimo derinys, t. y. bet kuris veikimas turi savo normatyvinius ir institucinius apribojimus, kurie apibrèžia veikimo ribas per nustatytas ir nusistovëjusias vertybes ir procedūras. Tačiau struktūrinių apribojimų suvokimas toli gražu neleidžia ignoruoti to fakto, jog veikèjai žaidžia strateginius žaidimus ${ }^{11}$. Taigi kasdienę valstybių sąveikų praktiką galima apibūdinti žaidimo terminu, kuris pabrèžia sąveikų abipusiškumą, tam tikrų taisyklių, viena vertus, buvimą, kita vertus, formavimąsi paties žaidimo metu, ir pagaliau atkreipia dèmesị į veikẻjų sąmoningumą šiame procese, t. y. į ju strateginį, tai yra tikslingą elgimąsi.

Tačiau strateginis žaidimas retai būna vien tiesus ir aiškus žaidimas dèl aiškių tikslų. Užsienio politika (ir ypač diplomatija) labai dažnai vyksta simbolinėje erdvèje, kai konkretaus žaidimo objektas nėra svarbiausias tikslas, o jis yra žaidžiamas dèl kitų motyvų. Ypač simbolinių žaidimų analizei dèl savo kasdieniškumo ir įprastumo tinka „nereikšmingos“ užsienio politikos santykių problemos (ypač tada, kai jos tampa dvišalius santykius apibrèžiančiomis problemomis). Dèl to šiame straipsnyje nagrinejjamos dvišalès Rusijos ir Didžiosios Britanijos sąveikos yra apibūdinamos simbolinio žaidimo sąvoka: tarpusavio sąveikos buvo susijusios su įprastosios, kasdienés politikos dalykais, tačiau viso proceso metu dalis jų tapo simboliškai reikšmingomis abiems pusėms ir lèmè, jog buvo pradètas žaisti visai kitoks žaidimas. Kaip tik tai, koks žaidimas žaistas ir kokiu būdu, norima tiriamojoje dalyje išsiaiškinti.

Simbolinių žaidimų analizei pasitelkiama Duffy, Frederking ir Tucker ${ }^{12}$ pasiūlyta kalbinių žaidimų analizès strategija. Čia simboliniams žaidimams neatsitiktinai pritaikoma kalbinio žaidimo idejja. Žaidimai savo formą igauna per kalbą konkrečiame laike ir vietoje ${ }^{13}$. Pagal minètus autorius, bet kokiame kalbos žaidime reikia analizuoti tris argumentacijos aspektus: pirma, veikëjų vertybes

\footnotetext{
${ }^{10}$ Laffey, M., Weldes, J., Beyond Belief: Ideas and Symbolic Technologies in the Study of International Relations, European Journal of International Relations 3 (2), 1997, p. 208.

${ }^{11}$ Plačiau žr. Barnett, M., Culture, Strategy and Foreign Policy Change: Israel's Road to Oslo, European Journal of International Relations, 5 (1), 1999, p. 5-36.

${ }^{12}$ Pagal Duffy, G., Frederking, B. K., Tucker, S.A., Language Games: Dialogical Analysis of INF Negotiations. International Studies Quarterly 42, 1998, p. 271-294.

${ }^{13}$ Žr. pastarojo aspekto platesnę interpretaciją: Fierke, K. M., Links Across the Abyss: Language and Logic in International Relations, International Studies Quarterly 46, 2002, p. 351.
} 
bei nuostatas, antra, žaidimo faktus ir, trečia, vykstantį dialogą. Veikëju vertybiu ir nuostatų sistema šiuo atveju yra valstybės konceptualizacijos apie tai, kas yra svarbu tarptautinëje politikoje, kokia ju vieta joje ir kaip jos turètų veikti. Tai savo vietos šiame pasaulyje nusakymas, atskleidžiantis valstybės elgesio struktūrinius apribojimus. Faktų sudèliojimas toli gražu nėra savaime suprantamas užsièmimas, šis procesas leidžia identifikuoti tai, kas ir kaip laikyta reikšmingais dalykais. Dialogo analizė apima situacijos, kuri susiformavo sąveikos procese, analizę, o taip pat dvišalių žaidimų dinamikos įvertinimą dviejų valstybių užsienio politikos kontekste.

\section{Vertybinis Rusijos ir Didžiosios Britanijos santykių kontekstas}

Pirmasis žingsnis, analizuojant simbolinį žaidimą, yra veikëjų vertybių ir nuostatų sistemos suvokimas. Ši sistema visų pirma apima valstybių konceptualizacijas apie tarptautinę politiką ir savo vietos joje nusakymą, kuris leidžia atskleisti valstybės elgesio struktūrinius apribojimus. Užsienio politikos analizèje šias vertybes dažniausiai deklaruoja šalių užsienio politikos koncepcijos ar programos. Śio straipsnio kontekste yra svarbu suvokti svarbiausius Rusijos ir Didžiosios Britanijos pasaulěžiūrinius (ne)sutarimus, nurodančius ribas, kurių negalètų peržengti net pati pragmatiškiausia užsienio politikos strategija.

2007 m. Didžiojoje Britanijoje bei 2008 m. Rusijoje įvykusi vadovų kaita kartu su smarkiai besikeičiančiomis tarptautinės politikos aktualijomis suteikè progą abiejų valstybių vadovams peržiūrèti savo šalių užsienio politikos veikimo principus arba aiškiau juos nusakyti. Nei viena, nei kita valstybè nepadarė radikalių posūkių, o daugiau „,kodifikavo“" nusistovëjusią praktiką.

2008 m. vasaros pabaigoje Rusijos prezidentas Dmitrijus Medvedevas taip apibendrino Rusijos užsienio politikos veikimo principus: Rusija pripažįsta tarptautinės teisès viršenybę ir mano, kad pasaulyje turi vyrauti multipoliariškumas, ji nenori konfrontuoti nè su viena pasaulio valstybe; jos svarbiausias prioritetas - Rusijos piliečiu gynimas, kad ir kur jie begyventu, ir pagaliau, prisipažinimas, kad „Rusija, ir kitos pasaulio valstybės, turi regionu, kuriuose yra jos privilegijuotų interesų “14. Naujoje užsienio politikos koncepcijoje dar, be to, pabréžiama nacionalinio suvereniteto reikšmẻ ir aiškiau nurodomas dèmesys NVS regionui ${ }^{15}$.

Rusija puikiai suvokia ir stengiasi pabrèžti savo subjektiškumą tarptautinejje politikoje visų pirma akcentuodama savo teritoriškumą ir geopolitini pasaulio matymą, pasireiškianti per aiškios geografinès interesų sferos identifi-

\footnotetext{
${ }^{14}$ Интервью Дмитрия Медведева телеканалам «Россия», Первому, НТВ, 2008, 31 августа, http://www. kremlin.ru/appears/2008/08/31/1917_type63374type63379_205991.shtml, žiūrèta 2008-10-13.

${ }_{15}^{15}$ Концепция внешней политики Российской Федерации, žr. утверждена Президентом Российской Федерации Д.А.Медведевым 12 июля 2008 г., http://www.mid.ru/ns-osndoc.nsf/0e9272befa34209743 256c630042d1aa/d48737161a0bc944c32574870048d8f7? OpenDocument, žiūrèta 2008-08-15.
} 
kavimą. Pagarba nacionalinio suvereniteto principui turi vieną, tačiau svarbią išimti - ginti piliečius bet kur ir bet kada. Savotiška šio principo realizacija buvo po 2008 m. rugpjūtį prasidejjusių įvykių Gruzijoje dvi Rusijos suvereniomis pripažintos Gruzijos teritorijos. Taigi nepaisant skelbiamos pagarbos tarptautinès sistemos veikimo principams ir ypač JT institucijai, Rusija intensyviai siekia daryti įtaką tarptautinės sistemos taisyklių formulavimui ir performulavimui, viena iš didžiausių vertybių tarptautinèje erdvẻje laikydama pagarbą sau kaip įtakingai sistemos žaidëjai.

Naujasis Britanijos užsienio reikalų ministras Davidas Milibandas užsienio politikos prioritetus ir koncepciją išdèstė 2007 m. vasarą pasakytoje kalboje, kur Britanijos misija apibūdinta kaip siekis „,naudoti savo stiprybes taip, kad būdami gèrio jèga (force for good) pasaulyje būtume ir gèrio jèga Britanijai“"16. Britanijos galia buvo nusakyta kaip minkštosios ir kietosios galių derinys, skirtas tarptautiniam saugumui ir gerovei stiprinti, nevengti tarptautinio įsitraukimo, reaguojant į saugumo problemas. Ši tarptautinį įsitraukimą pats Milibandas įvardija „liberalaus intervencionizmo“" terminu ${ }^{17}$, nes „,siekiant likti gèrio jèga, reikia protingai derinti minkštają idèju ir įtakos galią su kietąa ekonominių bei karinių iniciatyvų ir intervencijų galia"18. Britanijos veikimas tarptautinejje politikoje, anot jos užsienio reikalų ministro, grịstas pirmiausia siekiu nugalèti idejjų mūši, po to įtakojant tarptautines institucijas (, daugiašalis veikimas nèra silpnuju pasirinkimas ${ }^{\prime 19}$ ), o jau tada galima galvoti apie įvairias sankcijas, neatmetant ir tiesioginės intervencijos galimybės. Mat bendrų vertybių neužtenka, jos turi būti išreikštos bendrose institucijose ${ }^{20}$.

Taigi nepaisant Rusijos siekio skirti dėmesi ,,saviems" regionams ir ginti nacionalinio suvereniteto svarbą ir Didžiosios Britanijos pastangų būti ,gèrio jėga“ ir ",atsakingo suvereniteto“21 skelbëja, pasaulèžiūrinės skirties tarp šiu dvieju valstybiu poziciju neįmanoma nusakyti kaip tiesmuko skirtumo tarp realistinès ir liberalios tarptautinės politikos matymo. Persidengiančią susikalbejjimo ir interpretacijų erdvę formuoja, viena vertus, tarptautinių institucijų reikšmės pripažinimas (Rusijos atveju, ypač JT), o kita vertus, ,"kietosios“ galios naudojimo privalumu suvokimas. Abi valstybės mato susipynusį pasaulị su transnacionalinėmis problemomis, kurių savarankiškai nė viena tarptautinių santykių veikëja nèra pajègi išspręsti.

Bandant suvokti analizuojamų valstybių vertybinius skirtumus iš pirmo žvilgsnio siūlosi skirtis tarp interesų (Rusija) ir vertybių (Didžioji Britanija) gy-

\footnotetext{
${ }^{16}$ Miliband, D., New Diplomacy: Challenges for Foreign Policy, Speech at the Chatham House Royal Institute of International Affiars, 2007, July 19, http://www.chathamhouse.org.uk/files/10188_190707miliband.pdf, žiūrèta 2008-09-12, p. 2.

${ }^{17}$ Lawson, D., David Miliband, Prospect Magazine, 2008, October, Issue 151, http://www.prospect-magazine. co.uk/article_details.php?id=10395, žiūrèta 2008-12-01.

${ }^{18}$ Miliband, New Diplomacy: Challenges for Foreign Policy, p. 3.

${ }^{19}$ Ten pat, p. 5-6.

${ }^{20}$ Miliband, D., Speech to the 2007 Labour Party conference, 2007, September 25, http://news.bbc.co.uk/1/ hi/uk_politics/7012356.stm, žiūrèta 2008-11-07.

${ }^{21}$ Lawson.
} 
nimo ir privilegijavimo. Juo labiau, kad skirtingas kalbejjimas apie tarptautinę politiką ir pačių žodžių vartojimas leistų lengvai daryti tokią išvadą. Tačiau priešstata tarp intereso ir vertybių šių valstybių užsienio politikos konceptualizacijose sunkiai gali būti išskirta kaip reikšminga. Pirmiausia dèl to, kad teorinès priešstatos tarp intereso ir vertybès nèra, interesas negimsta iš niekur, jis formuluojamas remiantis vertybinemis pozicijomis apie save, savo tikslus ir pasaulį ${ }^{22}$. Antra, tokia skirtis sukuria asimetrinę opoziciją tarp dviejų nuostatu, kur vertybiné pozicija yra morali, o interesais gricsta - amorali, ir dèl to paskirsto valstybes į geras ir blogas, o to kiekvienoje analizejje norisi išvengti.

Visgi egzistuojantys argumentacijos ir akcentų skirtumai, kalbant apie savo šalies politiką, leidžia kalbėti ir apie svarbų vertybinį užsienio politikos konceptualizacijos skirtumą. Kalbẻdama apie savo vietą tarptautinejje politikoje Didžioji Britanija akcentuoja dėmesį išorei (pvz., kaip ji prisidès prie problemu sprendimo), o Rusijos kalbëjimo strategija yra gynybinè, pradedanti nuo savęs ir savo nuostatų pagrindimo ir paskui su jomis kurianti išorinius santykius. Kiek, o dar svarbiau kaip tokie vertybiniai kontekstiniai panašumai ir skirtumai lemia konkrečius dvišalès užsienio politikos elgesio skirtumus, parodoma toliau.

\section{Rusijos ir Didžiosios Britanijos nesutarimų grandinè}

Antrasis žingsnis, analizuojant žaidimus pagal minètuosius Duffy, Frederking ir Tucker ${ }^{23}$, yra susijęs su faktų išsiskyrimu ir sudèliojimu. Tai nereiškia, kad bandoma išsiaiškinti, kas iš tiesų vyko. Čia bandoma išryškinti tai, kas tapo svarbu dvišaliuose Rusijos ir Didžiosios Britanijos santykiuose, kas pradèta laikyti reikšmingais įvykiais, kuriais remiantis tie santykiai ir buvo interpretuojami. Tai yra į žaidimą įeina ne tik tai, kaip žaidžiama, bet ir kaip atsirenkama, dẻl ko žaidžiama.

Atkreiptinas dèmesys, kad paskutiniuju kelerių metų santykius su Rusija dauguma valstybių nusakytų negatyviai. Prastëjančių santykių sąrašas yra ilgas - tai kasmet pasikartojantys ginčai dèl dujų tiekimo, JAV priešraketinio skydo statymas, nesutarimai dèl požiūrio į Irano branduolinę programą bei kovą su terorizmu, prekybiniai ginčai ir boikotai, sienų vaidai, diskusijos dèl rusakalbiu padèties ir panašiai. Šios problemos yra bendros, nors dažniausiai sprendžiamos ir dvišaliais santykiais, vienija daugiau mažiau daugumą Europos valstybių.

Didžiosios Britanijos ir Rusijos santykiai išsiskiria tuo, abi valstybès pripažista, jog net ir gana įtemptų Europos ir Rusijos santykių kontekste ju bendravimas „ypatingai nenormalus". Iškalbinga yra naujos 2008 m. Rusijos užsienio politikos koncepcijos pastraipa, skirta Rusijos santykiams su Europos valstybèms:

\footnotetext{
${ }^{22}$ Plačiau žr. Finnemore, M. National Interests in International Society, Ithaca: Cornell University Press, 1996.

${ }^{23}$ See Duffy, G., Frederking, B.K., Tucker, S.A., Language Games.
} 
Abipusiai naudingų santykių plètra su Vokietija, Prancūzija, Italija, Ispanija, Suomija, Graikija, Nyderlandais, Norvegija ir kai kuriomis kitomis Vakarų Europos valstybėmis yra svarbus išteklius ginant Rusijos interesus Europoje ir pasaulyje .... Rusija norètu, kad tokiu pat būdu būtų išnaudotas bendravimo potencialas ir su Didžiąja Britanija ${ }^{24}$.

Dar aiškesnis požiūris suformuluotas metais anksčiau pasirodžiusioje Rusijos 2007 m. užsienio politikos apžvalgoje: „Didžioji Britanija išlieka svarbi, nors ir sudètinga partnerè ${ }^{\prime 25}$. Tad Rusija gana greitai „kodifikavo“ savo dvišalius nesutarimus su britais kaip išsiskiriančiais iš kitų.

Ne mažesnis atsargumas atsiranda ir britiškoje pozicijoje. Štai 2008 m. liepą prieš pat Didžiosios Britanijos premjerui Gordonui Brownui pirmąkart susitinkant su taip pat neseniai išrinktu Rusijos prezidentu Dmitrijumi Medvedevu britiškos saugumo tarnybos išplatino pranešimą, kad Rusija laikoma trečia didžiausia grésme po "AlQaeda" ir Irano ${ }^{26}$. Savo ruožtu Parlamento bendruomenių rūmų Užsienio reikalų komitetas dar 2007 m. pastebėjo, kad dvišaliai santykiai per pastaruosius metus ,žzymiai pablogëjo“ (,deteriorated markedly“), juose ",būta labai daug dirgiklių" ("there has been a string of irritations") 27. Britanija buvo kiek atsargesnè deklaruodama prastus santykius (neoficialiais pareiškimais ar švelnesnėmis formuluotėmis), tačiau nė viena kita valstybė, su kuria palaikoma kasdienė užsienio politika, nebuvo taip išskirta.

Kokie „mikro“ įvykiai sukūrè prielaidas ir pagrindą kalbëjimui apie prastus ir prastėjančius Didžiosios Britanijos ir Rusijos santykius, kokius strateginius veiksmus („ejjimus“) ir kaip darẻ kiekviena iš pusių formuodamos dvišalių santykių žaidimą?

Akivaizdi dvišalè įtampa pradejjo formuotis 2006 m., kai pačioje metų pradžioje Rusijos slaptosios tarnybos apkaltino britų diplomatus šnipinejjant (tai padaryta per žiniasklaidą). Kaip įrodymai buvo pateikti netikruose akmenyse įdèti elektroniniai sekimo įrenginiai, esą rasti viename iš Maskvos parkų. Netrukus Rusijos federalinė saugumo tarnyba (FST) viešai apkaltino Didžiosios Britanijos ambasadą išnaudojant ju remiamas nevyriausybines organizacijas šnipinejjimui ${ }^{28}$. Anot vieno britų diplomatu, taip sistemingai prasidejjo „neoficialūs ir ginčytini, priešiški veiksmai Jungtinès Karalystès atžvilgiu“29. Britanija atsisakẻ komentuoti pasirodžiusius kaltinimus, Rusija istorijos toliau nebetęsè, ir šis incidentas toliau viešai nesiplètojo.

Dvišalių santykių sprogimas įvyko 2006 m. lapkritị, kai prasidëjo tai,

\footnotetext{
${ }^{24}$ Концепция внешней политики Российской Федерации.

25 Обзор внешней политики Российской Федерации, 2007, http://www.ln.mid.ru/ns-osndoc.nsf/0e927 2befa34209743256c630042d1aa/d925d1dd235d3ec7c32573060039aea4?OpenDocument, žiūrèta 200809-12.

${ }^{26}$ Webster, P., Russia rated UK's biggest threat after al-Qaeda and Iran, TimesOnline, 2008, July 4, http:// www.timesonline.co.uk/tol/news/uk/crime/article4265569.ece, žiūrèta 2008-10-01.

${ }^{27}$ Global Security: Russia, House of Commons Foreign Affairs Committee, Second Report of Session 2007-2008, Lodond: The Stationary Office Limited, 2007, http:/www.fco.gov.uk/resources/en/pdf/RussiaGlobal-Security, žiūrèta 2008-09-14, P. 43.

${ }^{28}$ UK diplomats in Moscow spying row, $B B C$ News, 2006, January 23, http://news.bbc.co.uk/2/hi/europe/4638136.stm, žiūrèta 2008-08-02.

${ }^{29}$ Global Security: Russia, p. 43
} 
kas paskui pradèta vadinti „Litvinenkos byla“30. Londone gyvenęs buvęs Rusijos specialiujų tarnybų agentas Aleksandras Litvinenka mirè dẻl apnuodijimo radioaktyvia medžiaga, prieš mirtį apkaltinęs tuometinį Rusijos prezidentą Vladimirą Putiną suplanuota žmogžudyste. Scotland Yardui betiriant bylą pamažu pradeda aiškèti pagrindinis įtariamasis - buvęs KGB pareigūnas Andrëjus Lugavojus. Ši istorija pradeda dar labiau komplikuotis britams paprašius Lugavojaus ekstradicijos, kurią patenkinti Rusija atsisakè, motyvuodama Rusijos konstitucijoje numatytu draudimu šalies piliečius ekstradikuoti į užsienio valstybę, kur jie galètu būti teisiami. Rusijos pusè taip pat tvirtino, kad britai elgiasi nekorektiškai, nepateikdami aiškių įrodymų ir užmiršdami, kad rusai daug kartų prašè išduoti Rusijos piliečius, gyvenančius Didžiojoje Britanijoje ir primindami Boriso Berezovskio atvejį $i^{31}$. Didžioji Britanija savo ruožtu bandẻ apeliuoti į teisingumo principus ir siekè klausimą išlaikyti teisinių ginčų erdvëje.

Didžioji dalis konkrečių incidentų prasidejjo inicijuojant Rusijai arba tik netiesiogiai Didžiajai Britanijai. Bet 2007 liepą įvyko pirmasis akivaizdus Didžiosios Britanijos diplomatinis demaršas. Britai nepatenkinti tuo, kaip Rusija nebendradarbiauja aiškinantis Litvinenko žūties istoriją ir atsisakè išduoti britams pagrindinį įtariamaji Lugavoju, iš šalies išsiuntè keturis Rusijos diplomatus.

Rusija beveik nedelsdama èmèsi „,analogišku ir subalansuotu“ “32 atsakomuju priemonių ir išsiuntẻ keturis britų diplomatus iš savo šalies (be to, dar užšaldè specialiujuc tarnybų bendradarbiavimą ir derybas dèl kultūros centrų, taip sudarydama prielaidas būsimam Britų Tarybos „skandalui““33), savo žingsnius komentuodama taip:

Maskvos žingsniai ... yra pasverti ir kiek įmanoma būtini. Rusijos pusẻ buvo priversta imtis ju, atsižvelgdama į Londono sąmoningą pasirinkimą bloginti santykius su Rusija .... Tokiais atvejais visada veikia abipusiškumo principas, kuris yra tarptautinio bendravimo įstatymas. ... [britu pozicija] grįsta bet kuo, bet ne sveiku protu ir britams būdingu pragmatizmu bei pagarba įstatymams. Ką reiškia vien reikalavimas pakeisti Konstituciją, siekiant vieno įtariamojo „Litvinenkos byloje“ išdavimo. ... Tikimès, kad galų gale sveikas protas įsigalès ir Rusijos ir Didžiosios Britanijos santykiams netrukdys dirbtinès kliūtys, nesvarbu, ar tai būtų vidinès politikos konjunktūra, ar „Rusijos kortos“ naudojimas europinės ir euroatlantinės politikos kontekste. ${ }^{34}$

Didžiosios Britanijos parlamento ataskaitoje šie įvykiai buvo pakomentuoti kaip „rimčiausia dvišalių santykių krizè dvišaliuose diplomatiniuose santykiuose nuo šaltojo karo pabaigos “35.

\footnotetext{
${ }^{30}$ İykių chronologiją galima rasti čia http://www.litvinenko.org.uk/news/en/chronology/; arba Timeline: Litvinenko death case, BBC News, 2007, July 27, http://news.bbc.co.uk/2/hi/uk_news/6179074.stm, žiürèta 2008-07-20.

${ }^{31}$ Žr., pvz., Стенограмма ответа на вопрос СМИ Министра иностранных дел России С.В.Лаврова на пресс-конференции в Лиссабоне 19 июля 2007 года, http://www.mid.ru/ns-reuro.nsf/348bd0da1d5a71 85432569e700419c7a/432569d80022027ec325731e001fe7ff?OpenDocument, žiūrèta 2008-10-02.

${ }^{32}$ Ten pat.

${ }^{33}$ Ten pat.

${ }^{34}$ Министерство иностранных дел Российской Федерации, Комментарий МИД России по российскобританским отношениям, 2007, 19 июля, http://www.mid.ru/ns-reuro.nsf/348bd0da1d5a7185432569e 700419c7a/432569d80022027ec325731d004ad280?OpenDocument, žiūrèta 2008-09-04.

${ }^{35}$ Global Security: Russia, p. 11.
} 
Ne mažiau viešų aistrų ir didelio žiniasklaidos dėmesio susilaukẻ 2007 m. gale prasidèjęs Britų Tarybos „skandalas“. Ši ịstaiga Rusijoje veikia nuo 1992 m. ir kurị laiką turëjo diplomatinį statusą. 2004 m. Rusijos užsienio reikalu ministerija pareiške, kad tarybos biuru ji nelaiko diplomatinès misijos padaliniais, o iniciatyvą perėmusi Vidaus reikalų ministerija pateikè kaltinimus dèl nelegalios veiklos (neteisètų mokymų) ir mokesčių nemokẻjimo. Britų Taryba i s šiuos kaltinimus sureagavo ir byla buvo nutraukta ${ }^{36}$.

Tačiau 2007 m. spalio mẻnesį Rusija pareikalauja sustabdyti visų organizacijos padalinių ne Maskvoje veiklą nuo $2008 \mathrm{~m}$. sausio 1 d., remdamasi $1995 \mathrm{~m}$. i̊statymu „Dèl užsienio kultūros ir informacijos centrų steigimo tvarkos ir veiklos sąlygų Rusijos Federacijos teritorijoje" ir rasdama politinių kaltinimų. Pavyzdžiui, Krasnojarske vietos valdžia apkaltino tarybą "smegenų naikinimu“ (angl. brain drain), nes institucija viliojanti rusus stipendijomis Britanijos universitetuose ${ }^{37}$. Britai tuo tarpu bande įrodyti, kad tai ambasados dalis, turinti diplomatinį imunitetą ${ }^{38}$, arba pabrèžti reikalavimu politiškumą ${ }^{39}$. Kita vertus, Rusijos užsienio reikalų ministras Sergejjus Lavrovas 2007 m. gruodžio 14 d. pareiškimu pasakè, kad puolimas tiesiogiai susijęs su „Litvinenkos byla“. Taigi lyg ir patvirtino britų prielaidas, tačiau vèliau tokio pobūdžio pasisakymų nebepasitaikè.

2008 m. sausi Jungtinės Karalystės ambasadorius buvo informuotas, kad bus imtasis ",griežtų priemonių", jei Sankt Peterburge ir Jekaterinburge nesiliaus veikę Britų Tarybos padaliniai, o galimas britu pusės pasipriešinimas pavadintas ,suplanuotomis provokacijomis kaitinti Rusijos ir Didžiosios Britanijos santykius " ${ }^{40}$. Kitą dieną FST iškvietė į apklausas keletą organizacijos darbuotojų, dar po poros dienu - sausio $17 \mathrm{~d}$. - Britų Tarybos biurai buvo uždaryti.

Per tuos kelis mėnesius, abieju pusių oficialūs asmenys išsakè iškalbingu ir griežtų pareiškimu. Didžiosios Britanijos ambasadorius Anthony Brentonas tvirtino, kad „kad Rusija yra vienintelè nukentejusioji šioje istorijoje ${ }^{\text {“41 }}$, o kalbėdamas tą nakti, kai FST apklausinèjo Tarybos darbuotojus, darè nuorodas i Šaltajji karą ir Tarybų sajungos metodus tvarkytis su problemomis. Milibandas kaltino Rusiją ",akivaizdžiu gąsdinimu“ ir vadino tai "dème“ Rusijos užsienio politikoje. Britų užsienio reikalų ministras pabrèžè, kad Britų Taryba užims

\footnotetext{
${ }^{36}$ МИД РФ проводит антисоветскую политику, Коммерсантъ, 2007, 14 июня, http://www.kommersant. ru/doc.aspx?DocsID=773984, žiūrèta 2008-09-25.

${ }^{37}$ Buckley, N., Moscow steps up pressure in Moscow, Financial Times, 2007, 14 June, http://www.ft.com/ cms/s/0/5f94d026-1a86-11dc-8bf0-000b5df10621.html?nclick check=1, žiūrèta 2008-10-12.

${ }^{38}$ Franklin, K., Russia to restrict British Council, Telegraph,2007, 13 December, http://www.telegraph.co.uk/ news/uknews/1572370/Russia-to-restrict-British-Council.html, žiūrèta 2008-10-02.

${ }^{39}$ Wingfield - Haye.

${ }^{40}$ Министерство иностранных дел Российской Федерации, O вызове в МИД России посла Великобритании, 2008, 14 января, http://www.mid.ru/ns-reuro.nsf/348bd0da1d5a7185432569e700419 c7a/432569d80022027ec32573d00042fa0e?OpenDocument, žiūrèta 2008-09-16.

${ }^{41}$ Посол Великобритании о Британском совете: „Единственной пострадавшей в этой истории оказалась Россия“, Коммерсантъ, 2008, 1 января, http://www.kommersant.ru/doc.aspx?DocsID=843045, žiūrèta 2008-09-12.
} 
„moralią poziciją" (moral high ground) ${ }^{42}$, pridėdamas: „nusprendžiau nesiimti panašių veiksmų Rusijos kultūrinės veiklos Jungtinëje karalystëje atžvilgiu“43.

Savo ruožtu Lavrovas komentuodamas tebesitęsiančią Britų Tarybos veiklą Sankt Peterburge ir Jekaterinburge teigè, kad tai rodo „kolonijinių laikų nostalgiją", tvirtindamas, kad tokia kalba [kuria kalba Didžioji Britanija] su Rusija šnekètis negalima ${ }^{44}$. Taip pat nevengta ir kaltinimų rusų viliojimu iš šalies ${ }^{45}$.

Taip 2008-iesiems įsibėgejjus abiems pusẻms beliko padaryti išvadas apie itin blogus tarpusavio santykius ir prastas ju perspektyvas. Pagal Rusijos Užsienio reikalų ministeriją:

Šiuo metu [2008 m. gegužè] Rusijos ir Britanijos santykiai ne patys geriausiai. 2007 m. liepos $16 \mathrm{~d}$. Britanijos vyriausybė pretekstu pasirinkusi tariamą Maskvos atsisakymą bendradarbiauti taip vadinamoje "Litvinenkos byloje“ paskelbė pradedanti imtis nedraugišku veiksmų Rusijos atžvilgiu... Tik išsiuntęs iš Didžiosios Britanijos keturis rusų diplomatus oficialusis Londonas pranešè ribojantis bendradarbiavimą vizu, karinio techninio bendradarbiavimo srityje, o taip pat apie santykių su FST užšaldymą, o tai sukèlè grèsmę pastaraisiais metais susiklosčiusiam dvišaliam antiteroristiniam bendradarbiavimui ${ }^{46}$.

2007 m. Užsienio politikos apžvalgoje taip pat teigiama, kad „nepaisant mūsų bendradarbiavimo mastų, dvišalius santykius ir veiklą tarptautinejje arenoje riboja didžiosios dalies Britanijos politinio elito atvirai mesianistinès nuostatos, tarp jų ir vidiniu politinių procesų Rusijoje atžvilgiu“47.

Britų Užsienio ir sandraugos reikalų tarnyba taip pat neatsilieka savo skeptišku vertinimu:

Sutinkame, kad tarp Rusijos ir Jungtinès Karalystès tam tikrais klausimais egzistuoja nesutarimu, tarp kurių išsiskiria JK didesnis siekis palaikyti kišimąsi į valstybės vidaus reikalus, ypač žmogaus teisiu, demokratijos ir teisės viršenybės srityje. JK tiki, kad išorinis įsitraukimas gali būti svarbus siekiant tarptautinės taikos ir saugumo. Mes ir toliau rekomenduosime tai Rusijai. ... Kur nesutariame, mes stengsimės aiškinti, kodèl užimame tokią poziciją. Tačiau turime aiškiai pasakyti, kad kartais Rusijos elgesys neatitinka jos pačios savanoriškai prisiimtų tarptautinių įsipareigojimų demokratijai, žmogaus teisèms ir teisès viršenybei ${ }^{48}$.

Žinoma, dabar dar sunku pasakyti, ar 2008 m. bus paskutiniai tokio dvišalio žaidimo metai. Tačiau jau dabar šis gana trumpas dvišalių santykių laikotarpis suteikia medžiagos panagrinèti Rusijos ir Didžiosios Britanijos

\footnotetext{
${ }^{42}$ In full: Miliband Russia statement, $B B C$ News, 2008, January 18, http://news.bbc.co.uk/2/hi/uk_news/ politics/7194258.stm, žiūrèta 2008-09-21.

${ }^{43}$ Ten pat.

${ }^{44}$ Russia, Britain in slanging match over cultural centres, AFP, 2008, January 15, http://afp.google.com/ article/ALeqM5jH4TWhgv1gQmM6utJgvlvurivZGA, žiūrèta 2008-09-16.

${ }^{45}$ Pvz., Buckley..

${ }^{46}$ Министерство иностранных дел Российской Федерации, Российско-британские отношения (справочная информация), 2008, 15 мая, http:/www.mid.ru/ns-reuro.nsf/348bd0da1d5a7185432569e7 00419c7a/4fac8df9d8f7ddaf43256d4f00202087?OpenDocument, žiūrèta 2008-09-04

${ }^{47}$ Обзор внешней политики Российской Федерации.

${ }^{48}$ Response of the Secretary of State for Foreign and Commonwealth Affairs to Second Report from Foreign Affairs Committee Global Security: Russia, 2008, February, http://www.fco.gov.uk/resources/en/pdf/ FAC-Response, žiūrèta 2008-09-18, p. 3-4.
} 
dvišalę sąveiką ir suprasti, kokio pobūdžio simbolinį žaidimą ir kaip žaidė abi valstybès.

\section{Politiniai žaidimai kaip simbolinès galios išraiška}

Išanalizuoti atvejai parodo, kaip užsienio politikos veiksmai yra susiję ne tik kaip įvykių (veiksmų ir atoveiksmių) grandinè, bet ir per savo simbolines diskursyvines prasmes, susiejančias iš pirmo žvilgsnio „nelogiškus“, tarpusavyje nesusijusius reiškinius ir įvykius. Taip per dvejus metus dvi valstybės perëjo nuo tiesiog pakenčiamų dvišalių santykiu prie santykiu, kuriuos abi pradejo vadinti daugiau nei sudètingais.

Tad lieka paskutinis žingsnis - atskleisti, koks simbolinis žaidimas vyko. Taigi kokį žaidimą žaidè abi pusės? Ką viena kitai norèjo „pranešti“ Rusija ir Didžioji Britanija? Kodèl Rusijos ir Didžiosios Britanijos santykiai turëjo suprastèti dèl tokio, atrodytu, trivialaus dalyko kaip kažkokio saugumiečio konspiracijos teorijos? Kodèl reikia taip garsiai užsipulti užsienio kultūrinę švietejjišką organizaciją ir demonizuoti jos veiklą? Kodèl reikia viešai kaltinti vienas kitą šnipinëjant?

Bandant nusakyti, koks žaidimas žaistas, pirma, svarbu suvokti, kad tarp Rusijos ir Didžiosios Britanijos vyko asimetrinis žaidimas. Daugiau nei dvejus metus vykęs procesas parodè, kad būtent Rusija žaidè su Didžiaja Britanija. Ši, tiesa, keliskart bande perimti žaidimo iniciatyvą ar bent jau išlyginti pusiausvyrą, tačiau taip ir nesugebejo pati savarankiškai ir iniciatyviai pažaisti su Rusija. Dèl to reaktyvi Didžiosios Britanijos politika buvo gynybinè, piktesnè ir apeliuojanti į moralę, vertybes. Rusija savo ruožtu formulavo tvirtą poziciją ir neleido net pagalvoti, jog įmanoma kištis ị jos reikalus. Ši asimetriškumą, aišku, sustiprino ir tai, kad paties politinio spektaklio scena irgi dažniausiai buvo Rusijoje, o persikẻlimai į kitą erdvę žaidimo iniciatyvos neleido perimti. Metaforiškai šitokią situaciją gerai leidžia nusakyti „katès ir pelès“ žaidimas, kur tik vienas žaidejjas gali dominuoti. Didžiajai Britanijai nepavyko nei pasikeisti vaidmenimis, nei pakeisti žaidimo (pavyzdžiui, kad ir pereiti i „ „Tomo ir Džerio“ versiją).

Antra, dar kartą svarbu atkreipti dėmesị, kad vyko simbolinis žaidimas. Straipsnio pradžioje keltą svarbią tyrimo prielaidą atlikta analizė kaip tik ir patvirtino. Tam tikru metu vykusi konkreti dvišalių santykių problema dažniausiai nebuvo svarbi pati savaime - beveik visada tureta mintyje, arba manyta, kad kiti turi mintyje, visai kitą problemą (kartais net tiesiogiai tai pasakant, kartais susiejant per bendresnius elgesio apibūdinimus - „kolonijiné", „nedemokratiška“, „neteisinga“ ir pan.). Net nesvarbu, ar sutapo pusiu įsivaizdavimas, kokia problema iš tiesu turima mintyje - pakako vien to, kad yra įsivaizduojama, kad suprantama. Tai itin akivaizdu „šnipų skandaluose“ ar Britų Tarybos atveju.

„Litvinenkos byla“, tiesa, iš pradžių buvo kiek kitokio pobūdžio sąveika. 
Dèl to, kad šios problemos pagrindiniai įvykiai plètojosi Didžiojoje Britanijoje ir buvo susiję su pavojumi žmoniu gyvybei, šiai šaliai įvykis iš pradžių net nebuvo užsienio politikos žaidimas, jis buvo neatsiejamas nuo visuomenės saugumo problemos, todẻl labai „kūniškas" ir apčiuopiamas. Rusijai šis įvykis tapo gerokai reikšmingesnis, pagrindiniam veikëjui Litvinenko apkaltinus šalies prezidentą sąmokslu. Kaip tik tuomet tai tapo ne tik nepaklusnaus ir nepatikimo piliečio problema, o pagarbos šaliai, jos vadovui, o vèliau ir jos piliečiams (Lugavojaus atveju) klausimu. Didžiosios Britanijos vėlesni komentarai, kai ji stengèsi išpainioti sudètingą bylą, likdama teisiniame diskurse, taip pat rodo, kaip pamažu nunuodijimo byla ir jai išsivystè i pagarbos valstybei ir jos vertybèms klausimą.

"Litvinenkos byla“ iš dalies ir dèl to, kad įvykis tapo diskusija apie abipusę pagarbą, draugiškumą ir pasitikèjimą (o tiksliau šių elementu nebuvimą dvišaliuose santykiuose) vis dar lieka centriniu simboliniu žaidimu. Tai yra pagrindinis įvykis, į kurị nurodoma kuriant ar bandant spręsti dvišalius santykius. Čia kartu atsiskleidžia ir trečiasis Didžiosios Britanijos ir Rusijos simbolinio žaidimo bruožas - apibrěžiančioji žaidimų funkcija. Kitaip tariant, per simbolinius žaidimus užsienio politika atsiskleidžia kaip tapatybiu kūrimo procesas ${ }^{49}$. Analizuojamu atveju, ypatingai kaip kito apibrèžčiu kūrimas.

Pavyzdžiui, Rusija naudodamasi „,kolonializmo“ terminu pabandė perimti iniciatyvą radikaliai keisdama varžovo įvardijimą. Apkaltinti Britaniją, jog ji niekaip neužmiršta savo kolonijinès praeities - tai reiškia pasirinkti tą pačią diskursyvinę strategiją, kuri naudojama pačiai Rusijai apibūdinti. Tai puikus būdas neutralizuoti „,neoimperializmo“ terminą, vis dažniau pradètą naudoti apibūdinant Rusijos užsienio politikos veikimą. Nurodymas, kad užsienio politikos partneris (varžovas) elgiasi lygiai taip pat siekia sukurti pusiausvyrą, ir iš esmès Britanijai palieka vienintelị kozirị - „demokratijos ir žmogaus teisiu diskursą", kurị Britanija bando išnaudoti kurdama poziciją Rusijos atžvilgiu ${ }^{50}$. Tačiau konkrečiuose čia aptartuose atvejuose ji naudoti tapo sunku dèl žaidimų turinio specifiškumo - Rusija iš esmès sugebejo atsispirti vertybiniam jų konceptualizavimui, kiek įmanoma stengdamasi išlikti neutrali, objektyvi, teisinès kalbos valstybè.

Taigi Rusija perėmė dvišalių santykių formavimo ir formulavimo iniciatyvą, iš esmès ne tik nustatydama kokiais klausimais yra kalbama, bet ir nurodydama pokalbio intonacijas, dinamiką ir apibréžtis. Netgi sukūrusi lygiavertị santykị (kolonijinio-imperinio ịvardijimo atveju) Rusija sugebėjo igyti pranašumą, nes tokiu būdu ji pabandè griauti asimetrini, nepalanku jai, ir vis smarkiau ịsigalintị jos elgesio apibūdinimą tarptautinèje politikoje ${ }^{51}$.

\footnotetext{
${ }^{49}$ Žr. pvz., Campbell, D., Writing Security: United States Foreign Policy and the Politics of Identity. Minneapolis: University of Minnesota Press, 1992.

${ }^{50}$ Žr., pvz., Global Security: Russia.

${ }^{51}$ Tiesa, būtina pastebèti, kad strategija, siekiant pusiausvyros per kitu apibrèžimus, santykinai buvusi sèkminga analizuojamo atvejo kontekste, toli gražu nereiškia, kad ji visada sèkmingai veikia bendresnèje Rusijos tarptautinio veikimo strategijoje.
} 
Pagaliau dar vienas reikšmingas analizuojamo dvišalio žaidimo aspektas yra tai, jog kaip tik Rusija geriausiai sugebėjo išnaudoti teisinę retorika, leidusią nesunkiai priešintis vertybiniam, dèl to ir lengviau emocingumu apkaltinam oponentų kalbëjimo būdui (pavyzdžiui, „britų bandymas politizuoti temą, iškreipti faktus ir naudoti nekonstruktyvią retoriką nepadeda gerinti dvišalių santykių “52). Naudojant teisès kalbą dažniausiai pabrěžiamas racionalumas ir „sveikas protas“", objektyvumas. İdomu, kad tai vèl savybès, labai dažnai priskiriamos britams, i kurias analizuojamose situacijose pretenduoja būtent Rusijos pusè. Taigi vèl galime pamatyti panašią strategija, kaip ir kitų apibūdinimų kūrimo atveju: paneigti, neutralizuoti ",tradicinius" priešininku privalumus, juos priskiriant sau.

Galima pastebėti, kad tokio nesubalansuoto žaidimo prielaidas gali paaiškinti ir abieju valstybių vertybinis kontekstas, nagrinètas antroje straipsnio dalyje. Didžiosios Britanijos tarptautinio elgesio strategija yra visų pirma grįsta išorinio patvirtinimo ir išorinių (sẻkmingu) rezultatų poreikiu, kuris, žaidimu su Rusija atveju, nebuvo realizuotas. Tuo tarpu Rusijos savivokos apibrèžimas nereikalauja pirminio patvirtinimo - išorinè strategija jai atlieka savo tapatybès manifestacijos kitiems funkciją. Jai svarbus simbolinis tikslas, ryškèjantis ir iš jos dvišalių santykių su Didžiąa Britanija, yra stengtis, kad kiti priimtų ar suvoktų jos saviinterpretaciją: kad Rusija yra tvirta, racionali valstybe், kad ji tai suvokia todèl sieks pagarbos ir neleis savęs "stumdyti".

Tad 2006 - 2008 metų Rusijos ir Didžiosios Britanijos dvišaliai įvykiai buvo ne tik tiesioginiai retoriniai dviejų valstybių konfliktai dẻl keleto skirtingu, nors tarpusavyje ir susijusių klausimų. Tai buvo ir žaidimai, kur suprasta, kad kovojama ne dèl tiesioginės pergalès konkrečiu klausimu, o dèl kitu, daug svarbesnių dalykų. Dèl to ir konfliktuose ištarti žodžiai turëjo svarbesnę reikšmę nei pats konfliktas. Jais norėta ne tik nusakyti savo pozicijas konkrečiu klausimu, bet ir įtvirtinti savo santykines pozicijas bendrose dvišalių santykių diskusijose. Kitaip tariant, žodžiai bei abipusiai veiksmai atliko simbolinę funkciją. Taigi nekonfliktišku, bet kartu ir nedraugiškų dvišalių santykių dinamiką galima analizuoti per abieju pusių pateikiamus problemų ir situacijos apibūdinimus bei nagrinejjant svariausius jų argumentus.

\section{Vietoje išvadụ}

Viena iš populiarių nuostatų, vertinant žodžius realistinëje diplomatinejje kalboje, yra ta, kad diplomatai lengvai jų atsižada ir tai sukelia mažai pasekmių. Čia parodoma, kad ištarti žodžiai lieka politinio žaidimo dalyviai. Dalyviais jie išlieka ne tiek dèl to, kad jie yra prisimenami ir primenami, o visu pirma dèl to, kad nuolat juos kartojant, cituojant ir perfrazuojant, jie pradeda gyventi savo gyvenimą. Jie gali išnykti iš aktyvios diskursyvinės erdvès kuriam laikui, bet gali nesunkiai būti „atgaivinti“ - vèl padaryti veikëjais. Kaip kad

\footnotetext{
${ }^{52}$ Комментарий официального представителя МИД России М. Л. Камынина.
} 
atsitinka su Litvinenkos kaltinimais Putinui ar tariamais, o gal tikrais Lavrovo keiksmažodžiais Milibandui jau po Gruzijos įvykių.

Be abejo, straipsnyje analizuojami reikšmių kūrimo procesai nẻra vieninteliai formuojantys ir nusakantys dvišalius valstybių santykius. Tiek kasdienė sąveika, tiek išskirtiniai, proginiai įvykiai, tiek tarptautinės aplinkos kontekstas, tiek vidiniai procesai šalyse daro įtaką ir leidžia suprasti valstybių užsienio politiką. Simbolinių užsienio politikos žaidimų analizė atskleidžia, kaip valstybės strategiškai ir kūrybingai veikia tarptautinejje politikoje per įvardijimus, apibūdinimus ir kalbines strategijas pasiekdamos ar prarasdamos iniciatyvą dvišaliuose santykiuose ir spręsdamos savo ar dvišales problemas. 2006-2008 m. Didžiosios Britanijos ir Rusijos atvejis buvo palankus analizei dèl to, kad keitimosi reikšmėmis ir konkurencijos dèl jų procesas vyko labai intensyviai, koncentruotai ir tikslingai.

Tokią įtampą, nepajudant kur nors toliau, gana sunku išlaikyti ir, tikètina, kad abiejų valstybių santykiai pamažu taps apibūdinami kaip "normalūs", neišsiskiriantys nuo santykių su dauguma kitų Europos valstybių. Kita vertus, tai nereikš, kad iš santykių tarp valstybių išnyks simbolinès kovos, kaip jos neišnyksta daugelyje dvišalių sąveiku, tik jos pasireiškia per ilgesnį laikotarpi ir ne tokiomis atviromis kovomis. 